\title{
Feasibility Study of Bonyoh Adventure Trail Tourism Business in Bonyoh Traditional Village, Kintamani District
}

\author{
A. A. Istri Dewi Adhi Utami ${ }^{1}$, I Nengah Suastika \\ adhi.utami@undiksha.ac.id \\ ${ }^{1}$ Universitas Pendidikan Ganesha, Indonesia
}

\begin{abstract}
This study aims to examine the feasibility study of the Bonyoh Adventure Trail business in Bonyoh Traditional Village, Kintamani District seen from financial aspects and non-financial aspects which include legal aspects, economic and cultural aspects, market and marketing aspects, technical and technological aspects, management and financial aspects. . The method used is qualitative research methods and descriptive statistics. The instrument of data collection was checklist technique, interview guide and documentation study guide. The data analysis technique used is qualitative data analysis on legal aspects, economic and cultural aspects, market and marketing aspects, technical and technological aspects, and management aspects. In the financial aspect, 2 (two) investment feasibility methods are used, namely: payback period (PP), net present value (NPV). The results of the analysis show that the Bonyoh Adventure Trail business in terms of legal aspects is not feasible, economic and cultural aspects are feasible, market and marketing aspects are feasible, technical and technological aspects are feasible, management aspects are feasible and financial aspects are feasible, namely the results of calculations PP is 2 months 10 days < the economic life of the equipment used is 3 years, and the NPV calculation result is Rp. $920.000 .000>0$ (Positive).
\end{abstract}

Keywords: Feasibility study; adventure trails; business

\begin{abstract}
1 Introduction
Before establishing a business, a business feasibility study is a necessity to ensure that the established business can develop well and is needed by the market. Several studies show that businesses carried out without a business feasibility study first experience problems after they are established and run. The problems that often arise when a business is established without a business feasibility study are: (1) the business does not develop properly because it is not needed by the market, (2) the management system does not function, so the business must be stopped, (3) venture capital what is needed to make the business run normally is not met, so that the business cannot be continued, (4) there are demands from the community to close the business being carried out, because it is not in accordance with the customs and traditions of the community or pollutes the community environment, and (5) is terminated by law. law
\end{abstract}


enforcement because the business being carried out is illegal [19]. On the other hand, business feasibility studies are urgently needed by investors to ensure their business runs well, banks or financial institutions to provide credit and business owners to continue their business establishment. A business feasibility study is research that involves various aspects, from legal, socio-economic and cultural aspects, market and marketing aspects, technical and technological aspects to management and financial aspects, all of which are used as a basis for feasibility study research and the results are used to take the decision whether a project or business can be carried out or postponed and even discontinued [17].

Business feasibility studies can be viewed from various aspects such as marketing, management aspects, financial aspects, juridical aspects, sociological aspects, and environmental aspects. The business feasibility study involves: 1). The legal aspect, namely the legality of the business to be established, concerns: a) licensing, namely location permits, certificates, proof of paying land and building taxes, recommendations for village meetings, $b$ ) business permits regarding the deed of establishment, taxpayer identification number (NPWP), and SIUP ; 2). Socio-economic and cultural aspects, namely the influence of village business entities on people's lives, village customary habits, community income, employment opportunities, changes in work wages, community conditions, community education, communication patterns and the community's desire to advance the village; 3 ). Market and marketing aspects, namely the existence of market opportunities to require the products to be offered as well as the strategies adopted to reach potential markets related to the number of potential customers, people's purchasing power, how to market products and marketing resources; 4). Technical and technological aspects, namely business location, office facilities, production equipment and technology used in the business; 5). The management aspect, namely the management of the business to be built and the human resources already owned to run the business to be created; and 6). Financial aspects, namely the business capital needed for business operations, sources of funds and the assumption of profits that will be obtained when the business has been run [18].

\section{Methods}

The method used is qualitative research methods and descriptive statistics. The instrument of data collection was checklist technique, interview guide and documentation study guide. The data analysis technique used is qualitative data analysis on legal aspects, economic and cultural aspects, market and marketing aspects, technical and technological aspects, and management aspects. Methodologically this research uses qualitative research methods with descriptive statistics (Creswell, J. W. 2008). This selection is based on an analysis of the research problem, which demands a number of field information that emerges from below that cannot be separated from the natural setting of the research. The location of this research is the Bonyoh Traditional Village, Kintamani District, Bangli Regency which is developing a Bonyoh Adventure Trail tourism business. The research subjects consisted of several parties who based on consideration were judged to have the quality and accuracy to act as research subjects, namely the tourism awareness group, trail bike community, Bendesa Adat Bonyoh, community leaders in the Bonyoh Traditional Village, the head of the youth organization of Bonyoh Traditional Village and the Bonyoh Traditional Village community. (Sugiyono. 2010). The technique of withdrawing research subjects was carried out purposively (purposive sampling technique), then the number and types were developed using a rolling "snowball sampling technique" until data saturation was achieved where information/data had been collected completely. Data collection techniques were carried out by checklists, interviews, and document studies (Goodson, L., \& Phillimore, J. (Eds.). 2004). While the research instrument used was a 
checklist technique, interview guide and documentation study guide which was developed by the researcher himself. The data analysis technique used is qualitative data analysis on legal aspects, economic and cultural aspects, market and marketing aspects, technical and technological aspects, and management aspects. In the financial aspect, 2 (two) investment feasibility methods are used, namely: payback period (PP), net present value (NPV). (Densin, N.K. \& Lincoln, Y.S. 2009; Sugiyono. 2010).

\section{Results and Diccussion Business Feasibility Study Process}

Bonyoh Traditional Village is one of the Bali Aga Villages that currently wants to establish a tourism business unit, namely Bonyoh Adventure Trail. Trale adventure is an adventure in the wild by using a motorbike to explore it (Exercise \& Mountains, 2020). This adventure requires terrain that is uphill, downhill, muddy, winding, narrow roads and full of challenges that can stimulate the adrenaline of motorcyclists. Bonyoh Traditional Village with a rural atmosphere, beautiful natural scenery, traditional socio-cultural conditions, cultural and agricultural activities, as well as ravines surrounding the village area are the main potentials for the development of trail adventure tourism businesses [14] . The expanse of orange groves along the Bonyoh Traditional Village area is also a special attraction for trail adventure enthusiasts to explore the Bonyoh Traditional Village area. Until now this potential has not been able to be optimized by the community, due to the lack of ability to make business plans, business management, packaging of tourism activities, product marketing and business capital needs. Meanwhile, the Bonyoh Traditional Village already has a trail lover community who often participates in events in various places with adequate experience on trail adventure terrain. These skills can be used as initial capital to develop a Bonyoh Trail Adventure tourism business.

In connection with the plan to establish a Bonyoh Adventure Trail tourism business, a business feasibility study is carried out to determine whether the business to be developed is relevant to the needs and applicable regulations. This activity will be carried out through lectures, questions and answers, focus group discussions and presentation of group assignments involving tourism awareness groups, Bonyoh Traditional Village administrators and the Bonyoh Adventure Trail community. The number of subjects involved in the activities were 20 people, consisting of 10 tourism-aware groups, 4 Bonyoh Traditional Village officials and 6 people from the Bonyoh Adventure Trail community. The activity begins with the provision of material by experts on business feasibility studies and the objectives of business feasibility studies for small and medium enterprises. A business feasibility study is a research activity carried out to determine the business to be built is indeed needed by the market and determines the business capital needed to establish it [1]. A business feasibility study is an activity carried out to determine whether a business is feasible or not. This activity includes identifying problems, opportunities, setting goals, describing how the business situation is and assessing the various benefits generated [4]. The objectives of a business feasibility study are: (1) to facilitate planning, (2) to avoid the risk of loss, (3) to facilitate the implementation of work, (4) to facilitate supervision, and (5) to facilitate control [5]. Planning is an activity carried out to determine what will be done later by scientifically predicting events that will occur in the future. The plan can be designed by involving the amount of capital, implementation time, location, implementation procedures, large profits, and monitoring of deviations [7]. With a careful calculation of the capital that will be needed, the location of the business, the procedures for carrying out the business, the duties of each employee, the benefits to be obtained, supervision of business activities and evaluation of the activities carried out, it is believed that the business will have certainty to continue sustainable. Avoiding losses is done by carefully calculating 
various aspects that need to be prepared for business activities. In business activities, several indicators can be controlled as needed, such as management, business capital, supervision, division of tasks and business location. Meanwhile, indicators that are volatile include market demand, selling value and business sentiment. With a business feasibility study, you can minimize losses, both easy and difficult to control [17].

Facilitating the implementation of work is done by determining in planning what work appears in the business being carried out. To complete the job, how many people are needed and what skills must be possessed to complete the job. With a division of labor system according to needs and competencies, it will make it easier for employees to work and stay focused on business goals [6]. Facilitating supervision is carried out by determining the stages of business activities, division of labor for employees, financial management, business development planning to the business supervision model. Careful planning will make it easier to see business developments and business conditions, so that appropriate action can be taken if there are events that will cause losses to the business [19]. Facilitate control by using a computerized system that is connected to a variety of software that can be controlled and transparent. Transparency in various aspects will make it easier to control deviations that may occur, because everyone knows the business policies, business objectives, rewards, and sanctions for deviant employees [16].

\section{Making Feasibility Study of Bonyoh Adventure Trail Business}

After being given material regarding the meaning and purpose of a business feasibility study, the activity continued with a focus group discussion, followed by conducting a business feasibility study by analyzing the aspects that must be met. First, analyzing the legal aspects, namely the process of analyzing the legal provisions that must be met in order to be able to set up a business. This legal aspect relates to indicators: (1) location permit for business establishment, (2) land ownership certificate, (3) proof of payment of land and building taxes, (4) recommendation for customary village deliberations, (5) business permit deed of establishment from a notary, (6) taxpayer identification number (NPWP), and (7) trading business license (SIUP). Second, analyzing the economic and cultural aspects, namely the increase or decrease in people's income due to the availability/closing of jobs that affect the socio-cultural life of the community [1]. Businesses that are built without taking into account the economic and cultural impacts often have negative implications for people's lives, such as closing employment opportunities, because the workers needed are skilled workers, while the community does not have these skills. The change in the cultural pattern of the community which was previously familial and agrarian to become an individual and industrial society, while most of the people are farmers. The implication is that only a small part of the community can be involved in these business activities and the previously available land has been diverted for industrial activities [5]. The analysis of economic and cultural aspects related to the Bonyoh Adventure Trail business is related to: (1) the influence of Bonyoh Trail Adventure on people's lives, (2) the influence of Bonyoh Trail Adventure on village customs, (3) the influence of Bonyoh Trail Adventure on people's income, (4) the influence of Bonyoh Trail Adventure on employment opportunities, (5) the effect of Bonyoh Trail Adventure on changes in wages, (6) the effect of Bonyoh Trail Adventure on community conditions, (7) the influence of Bonyoh Trail Adventure on public education, (8) the influence of Bonyoh Trail Adventure on communication patterns, and (9) the influence of Bonyoh Trail Adventure on the community's desire to develop the village.

The third is the analysis of market aspects and marketing are activities carried out by companies to promote a product or service that they have [10]. This marketing includes advertising, selling, and shipping products to other consumers or companies. In carrying out 
promotions, sellers will target people who are in accordance with the products being marketed. In this context, the people who are the target of marketing are trail premotors who like to go on adventures or adventures. When marketing is in accordance with the target, the company will get many buyers and profits can be obtained. The purpose of marketing is to introduce products to consumers, conduct market research, distribution and after-sales service [14]. Related to the analysis of market and marketing aspects: (1) there is a market opportunity to require the product to be offered, (2) the strategy taken to reach potential markets related to the number of potential customers, (3) people's purchasing power, (4) how to market products, and (5) marketing resources.

Fourth, analysis of technical and technological aspects is a tool used to support office operations, so that it can run according to company goals. The purpose of using technology is to simplify and speed up human work. Technology is also capable of being a means of transforming a more productive, efficient and timely work culture. The analysis on the technical and technological aspects relates to: (1) the location of the business, (2) office facilities and infrastructure, and (3) the production equipment and technology used in the business. Fifth, analysis of management aspects related to: (1) business management model, (2) owned human resources, and (3) company financial management. Sixth, analysis of financial aspects related to: (1) business capital needed for business operations, (2) sources of funds, and (3) assumptions about profits that will be obtained when the business is started.

\section{Conclusion}

This service activity begins with the process of providing material on the concept of a business feasibility study, the purpose of a business feasibility study and the urgency of a business feasibility study to build a business. Business feasibility studies in this activity are conducted to analyze and democratically formulate legal aspects, socio-economic and cultural aspects, market and marketing aspects, technical and technological aspects, management aspects, and financial aspects. The analysis of these aspects is carried out by deliberation in mentoring activities to find out what things need to be prepared to establish a Bonyoh Adventure Trail business. The results of the analysis show that the Bonyoh Adventure Trail business in terms of legal aspects is not feasible, economic and cultural aspects are feasible, market and marketing aspects are feasible, technical and technological aspects are feasible, management aspects are feasible and financial aspects are feasible, namely the results of calculations PP is 2 months 10 days < the economic life of the equipment used is 3 years, and the NPV calculation result is Rp. $920.000 .000>0$ (Positive).

\section{References}

[1] Arianton, K., Meitriana, M. A., \& Haris, I. A. (2019). Studi Kelayakan Usaha Budidaya Rumput Laut Pada. Jurnal Pendidikan Ekonom, 11(2), 573-582. https://ejournal.undiksha.ac.id/index.php/JJPE/article/view/21591/14008

[2] Berolahraga, K., \& Gunung, D. I. (2020). Jurnal Terapan Ilmu Ekonomi , Manajemen dan Bisnis The EFFECT OF PHYSICAL AND MENTAL BENEFITS ON SPORT. 1(1).

[3] Deviyanti, O. R. (2009). PELAYANAN PUBLIK BIDANG PERIZINAN ( Studi Mengenai Kualitas Penyelenggaraan Pelayanan Terpadu Satu Pintu Dalam Pengurusan Surat Izin Usaha Perdagangan ( SIUP) Di Kantor Pelayanan Terpadu Perizinan ( KPTP ) Kabupaten Kotawaringin Barat.

[4] Fernando, S., Castro, N., Fernandez, M., Pastor, C. K., Tabisola, C. T., \& David, C. E. 
(2020). Difficulties of Junior Business Administrators in Writing Research Paper and Feasibility Study Contents. Southeast Asian Journal of Science and Technology, 5(1), 1923. www.sajst.org

[5] Firdausi, I., Nidn, M. S., Amalia, H. S., Nidn, M. S., Nidn, L. G., \& Mandiri, S. D. (2021). STUDI KELAYAKAN BISNIS BUMDES MAJU JAYA DESA SUMBER MAKMUR KEC. TAKISUNG KAB . TALA Pelaksana :

[6] Gopaul, S. (2013). Feasibility Study for a Global Business Network on Apprenticeship (Issue August).

[7] Harahap, S. (2018). STUDI KELAYAKAN BISNIS Pendekatan Integratif.

[8] Hermawanto, R. (2014). Pelayanan Pembuatan Surat Izin Tempat Kota Samarinda EJournal Ilmu Administrasi Negara. 4(2), 1288-1300.

[9] Ismaniar Ismail, \& Rukmana, N. S. (2020). Responsivitas Pelayanan Publik Dalam Pengurusan Surat Izin Usaha Perdagangan Di Dinas Penanaman Modal Dan Pelayanan Terpadu Satu Pintu (Dpmptsp) Kabupaten Sinjai. Jurnal Administrasi Publik, 16(1), 12. https://doi.org/10.52316/jap.v16i1.27

[10] Kurniadi, D., \& Prahasto, T. (2016). Metode Forward Chaining Untuk Penentuan Kelayakan Bisnis Usaha Mikro. Jurnal Sistem Informasi Bisnis, 6(1), 66. https://doi.org/10.21456/vol6iss1pp66-75

[11] Laksmana, T. A., Rachmat, H., \& Tahir, R. (2020). Strategi Pengembangan Wisata Bersepeda Berdasarkan Karakteristik Motivasi Pesepeda Urban (Pada Grup Sepeda TOC Dan JGC-SCAM). Jurnal Pariwisata Terapan, 4(1), 73. https://doi.org/10.22146/jpt.54742

[12] Mahagangga, I., Suryawan, I., Nugroho, S., \& Sudana, I. (2016). Pemetaan Jalur "Paket Wisata Pedesaan" Di Desa Wisata Penglipuran, Kecamatan Bangli, Kabupaten Bangli. Jurnal Udayana Mengabdi, 15(2), 1-6.

[13] Ratnawati Ayu. (2017). Aspek hukum legalitas perusahaan atau badan usaha dalam kegiatan bisnis. Jurnal Hukum Samudra Keadilan, 12, 136-145.

[14] Rozaan, A., Kholid, M., \& Prasetya, A. (2018). Analisis Pengembangan Produk Wisata Heritage Trail Untuk Meningkatkan Citra Destinasi (Studi Pada Surabaya Heritage Track Di Surabaya). Jurnal Administrasi Bisnis (JAB), 61(4), 81-90.

[15] Suastika, I. N., et. al. (2019). Traditional Life of Bayung Gede Community and Its Development As Cultural Attraction. 3(1), 108-121.

[16] Sudiartini, N. W. A. (2020). The feasibility study of coffee house business opportunity in COVID-19 pandemic: a case study at kulo coffee shop pemogan. International Research Journal of Management, IT and Social Sciences, 38-45. https://doi.org/10.21744/irjmis.v7n5.966

[17] Sulastri, L. (2016). Studi Kelayakan Bisnis Untuk Wirausaha. In LaGood's.

[18] Supono. (2013). Scanned by CamScanner sرازمك. A Psicanalise Dos Contos de Fadas. Tradução Arlene Caetano, 466.

[19] Wardani, S., \& Katti, B. (2020). Penyuluhan Pentingnya Pembukuan Umkm Sederhana Dan Tahapan Penyusunan Studi Kelayakan Usaha. 5(September), 58-60.

[20] Yusmantoro, S., Hermansyah, E., \& Efendi, R. (2014). Rancang Bangun Aplikasi Pengamanan Keaslian Surat Izin Tempat Usaha Menggunakan Algoritma Elgamal Dan Secure Hash Algorithm 256 Studi Kasus: Badan Pelayanan Perizinan Terpadu (Bppt) Kota Bengkulu. Jurnal Rekursif, 28-36. https://ejournal.unib.ac.id/index.php/rekursif/article/view/303 